\title{
Evaluation of ColdZyme Mouth Spray against Common Cold in Elderly Care Personnel
}

\author{
Mats Clarsund ${ }^{1}$, Christina Bråkenhielm Persson² \\ ${ }^{1}$ Enzymatica AB, Lund, Sweden \\ ${ }^{2}$ Home Health Care, Social Sector, Eksjö kommun, Sweden \\ Email: mats.clarsund@enzymatica.com
}

How to cite this paper: Clarsund, M. and Persson, C.B. (2017) Evaluation of ColdZyme Mouth Spray against Common Cold in Elderly Care Personnel. Open Journal of Respiratory Diseases, 7, 12-17. https://doi.org/10.4236/ojrd.2017.71002

Received: October 4, 2016

Accepted: December 13, 2016

Published: December 16, 2016

Copyright $\odot 2017$ by authors and Scientific Research Publishing Inc. This work is licensed under the Creative Commons Attribution International License (CC BY 4.0).

http://creativecommons.org/licenses/by/4.0/ (c) (†) Open Access

\begin{abstract}
ColdZyme ${ }^{\oplus}$ Mouth Spray (ColdZyme) is a mouth spray intended to reduce the probability of catching a cold and/or can help shorten the duration of a cold if used at an early stage of the infection, by forming a barrier on the pharyngeal mucous membrane. This study evaluated the preventative effect of ColdZyme on common cold infections in personnel at elderly care facilities, and assessed the level of reduction in corresponding sick leave. The number of sick-leave days for the personnel decreased from an average of 5.2 days to 3.7 days (29\%) when using ColdZyme compared to control period $(p=0.054) .63 \%$ of those who had a cold reported the symptoms to be milder than previous colds. Conclusion: Using ColdZyme ${ }^{\circledast}$ Mouth Spray to apply a barrier to the oropharynx may be an easy and practical way to prevent or reduce infections of the common cold virus and corresponding sick leave in personnel working in elderly care.
\end{abstract}

\section{Keywords}

Common Cold, Elderly Care, ColdZyme ${ }^{\circledR}$ Mouth Spray

\section{Introduction}

Infectious outbreaks in elderly care facilities are likely to have a significant impact on infection rates and mortality rates of the residents and respiratory and gastrointestinal tract infections are the most common causes of outbreaks [1]. Elderly care residents are more vulnerable to infections than previously thought [2], due to decreased immunity, having multiple chronic diseases, decreased cognitive function and the use of invasive devices (e.g. urinary catheters and enteral feeding tubes). Mortality associated with outbreaks of respiratory tract infections due to any pathogen in long-term care facilities can be significant [3]. The risk of healthcare-associated infections and the spread of infection is also a 
reality in homecare settings of older people. Elderly care personnel are thus at risk for exposure to a variety of communicable diseases, and the risk for occupationally acquired infection is an unavoidable part of daily patient care [4]. An easy and practical method to prevent or reduce viral transmissions in the elderly care is highly wanted.

Epithelial cell layers in oral and nasal cavities form a physical and innate immune barrier against bacteria and viruses [5]. Yet, viruses can infect the mucosal cells in this area resulting in cold symptoms [5]. In order to prevent infection, the natural barrier can be strengthened by applying a glycerol- and enzymebased layer to the oropharyngeal mucosal membrane. This method was shown to be efficacious in a clinical study, in which the viral load significantly decreased $(\mathrm{p}=0.02)$ and the number of days with common cold symptoms for one episode was reduced from 6.5 days to 3 days, in comparison to placebo [6].

The specific conditions of elderly care are conducive for transmitting infectious agents. Consequences for infected staff often include reduced working capacity and absence from work. In general, upper respiratory tract infections accounts for the major fraction of all short term sick leave [7] [8]. The conceptual design of this observational study allowed the assessment of ColdZymes benefit in real-life setting, assessing effectiveness and long-term beneficial effect in terms of sick-leave days. ColdZyme ${ }^{\varpi}$ Mouth Spray (Enzymatica AB, Lund, Sweden) is a medical device against common cold, designed to deliver a solution containing primarily glycerol and trypsin to the mouth/ throat. It is intended to reduce the probability of catching a cold and to help shorten duration of a cold by creating/forming a thin protective barrier on the oropharyngeal mucous membrane.

\section{Methods}

This was a 5-month, open-label, observational product evaluation study, taking place during the cold season from November to March in Eksjö, Sweden. The study included nursing personnel at two elderly care units and personnel at a home nursing unit. In the municipality, approximately 282 nursing personnel were employed whereof 113 voluntarily accepted to be included in the evaluation. According to the local ethics committee, a formal approval from the committee was not necessary for this product evaluation. The subjects were advised to use ColdZyme according to the instructions on the device. For prevention, it is recommended to spray one dose every second hour when believed being exposed to cold virus and to obtain shortening of the duration of a cold it is recommended to start to spray one dose every second hour as soon as possible after noticing symptoms of a cold and continue until the symptoms are relieved.

Sick-leave data on the subjects included in the study were taken from the employer's database on absence from work for the control period (November to March the previous season) and treatment period (November to March). Statistical hypothesis for the analysis of sick-leave data were analyzed using paired, two-tailed Student's t test with a significance level of 5\%. All subjects were asked to fill in an electronic evaluation form, based on Google forms, containing qual- 
ity of life and product related questions anonymously two times during the study. A procedure for reporting adverse events was established. All subjects signed informed consent agreements; participation in the study was voluntary and subjects were free to withdraw their consent at any time.

Short term sick leave is defined as sick leave for 1 to 7 days. Subjects reporting $>29$ days of sick-leave during control and/or treatment period were excluded to remove sick leave due to other reasons than primarily common cold.

\section{Findings}

113 subjects out of 282 employees were included. $97 \%$ were female and a majority $(87 \%)$ were in the age range from 36 to 65 years. 111 subjects completed the study. 11 subjects not employed by the caregiver were excluded due to breach of inclusion criteria and that their historical sick leave data could not be verified. Further 24 subjects were excluded in the analysis due to having $>29$ sick-leave days (i.e. not short term sick leave). The analysis set was after exclusion based on 76 subjects. The total number of short term sick leave for the personnel during a 5-month period decreased from 392 days for the corresponding control period the previous winter season to 279 days when using ColdZyme $(\mathrm{p}=0.054)$ (Table 1). The average number of sick days per person decreased from 5.2 to 3.7 days.

All 113 subjects were asked to fill in an electronic evaluation form anonymously after two months and at the end of the study period. The answering frequency for the two evaluations was $49 \%$ which is low and therefore the results should be considered with some skepticism (Table 2). According to the instructions, ColdZyme can be used either preventatively (when exposed to virus) or when symptoms first appear. In this study, $76 \%$ of the subjects reported preventative use of ColdZyme and among those subjects who experienced a common cold $63 \%$ reported the symptoms to be milder than previous colds (i.e. much milder, milder and little milder).

To evaluate potential seasonal variances in sick-leave due to unusual low or high common cold frequencies during the treatment and control periods official data from Statistics Sweden (http://www.scb.se/en /) were analyzed. The reported sick-leave according to Statistics Sweden that is eligible for sickness benefits was slightly higher for the control period compared to the treatment period, 4.75 days compared to 4.53 days respectively but it can be concluded that neither control nor treatment period were during an unusual mild or severe common cold period.

\section{Discussion}

This study shows that use of ColdZyme by elderly care personnel might reduce short-term sick leave caused by the common cold. The design of this study was an open label un-blinded study without placebo and the risk of bias is high and therefore the results are preliminary. The subjects in the study were professional health care workers with a sound skepticism to common cold products in 
Table 1. Short term sick leave for nursing personnel from November to March $(n=76)$.

\begin{tabular}{ccccc}
\hline Measure & Control & ColdZyme & Difference & $\mathrm{P}^{\mathrm{a}}$ \\
\hline $\begin{array}{c}\text { Total sick leave days } \\
\text { Average sick leave days per } \\
\text { person }\end{array}$ & 392 & 279 & 113 & 0.054 \\
\hline
\end{tabular}

astudents t-test, two sided, paired.

Table 2. Quality of life and product assessment $(n=111)$.

\begin{tabular}{|c|c|c|}
\hline \multirow[t]{2}{*}{ Question } & \multicolumn{2}{|l|}{ Answer } \\
\hline & Parameter & $(\%)$ \\
\hline \multirow{2}{*}{ Have you used ColdZyme? $(\mathrm{n}=111)$} & Yes & 64 \\
\hline & No & 36 \\
\hline \multirow{2}{*}{$\begin{array}{l}\text { Have you had a cold during the study period? } \\
\qquad(\mathrm{n}=111)\end{array}$} & No & 40 \\
\hline & Yes & 60 \\
\hline \multirow{7}{*}{$\begin{array}{l}\text { How did you experience the cold(s) in this } \\
\text { study compared with previous colds? }(\mathrm{n}=46)\end{array}$} & Much milder & 21 \\
\hline & Milder & 24 \\
\hline & A little milder & 18 \\
\hline & Same & 30 \\
\hline & A bit worse & 2 \\
\hline & Worse & 2 \\
\hline & Much worse & 2 \\
\hline \multirow{5}{*}{ How did you use ColdZyme? $(\mathrm{n}=71)$} & Preventatively, daily doses & 45 \\
\hline & Preventatively when exposed & 31 \\
\hline & Preventatively and treatment & 10 \\
\hline & Treatment when having a cold & 7 \\
\hline & Other & 7 \\
\hline \multirow{3}{*}{ Would you recommend ColdZyme? $(\mathrm{n}=71)$} & Yes & 61 \\
\hline & No & 11 \\
\hline & Don't know & 28 \\
\hline
\end{tabular}

general including ColdZyme and to reduce potential bias in reporting cold symptoms the registered sick-leave at the employer's database was evaluated. In general, $60 \%$ of short term sick leave are due to upper respiratory infections [7] and using sick-leave as a performance parameter to evaluate the effect of ColdZyme against common cold will most probably underestimate the effect of the product. By including a comparison to historically data it is possible to estimate effect due to common cold reduction. The maximum achievable reduction of short term sick leave in this study if all common cold related sick leave could be prevented is estimated to a $60 \%$ reduction i.e. from 392 days to 157 days. Thus the resulting reduction in sick leave (113 days, 29\% reduction) when using ColdZyme could correspond to approximately $50 \%$ reduction in common cold related sick leave.

The questionnaire revealed a possible compliance issue where $37 \%$ of those who stated that they did not use ColdZyme reported they had a cold and should have been excluded from the data set due to non-compliance. However, there 
were no traceability between questionnaire and reported sick-leave. Interestingly, the majority of the subjects who used ColdZyme used it preventatively. Despite the modest severity of upper respiratory tract infections in most cases, it has a significant economic burden on society and on individuals. In a study by Hellgren et al. [9] they concluded that the mean productivity loss due to common cold and allergic rhinitis was estimated at 5.1 days or $€ 653$ per worker and year, yielding a total productivity loss in Sweden of $€ 2.7$ billion a year. The health economic impact due to the observed reduction in sick-leave, as observed in this study, is not to be neglected for the care unit and the employees.

In summary, this study supports the practical everyday use of ColdZyme in reducing the probability of infection or helping to shorten disease duration, if used at an early stage, of a naturally acquired common cold among elderly care personnel.

\section{Conclusion}

This product evaluation study showed that use of ColdZyme against common cold by nursing personnel working with elderly care reduced their short term sick-leave by $29 \%$. It can be concluded that applying a barrier to the pharyngeal mucous membrane is an easy and practical method to reduce transmissions of common cold viruses in the elderly care environment. Use of ColdZyme could also be beneficial to the economy and society as a whole due to the potential reduction in sick leave and associated costs.

\section{Acknowledgements}

The author thanks Marcus Fornbacke and Nathalie Nilsson for excellent work with this product evaluation study.

\section{References}

[1] Utsumi, M., Makimoto, K., Quroshi, N. and Ashida, N. (2010) Types of Infectious Outbreaks and Their Impact in Elderly Care Facilities: A Review of the Literature. Age and Ageing, 39, 299-305. https://doi.org/10.1093/ageing/afq029

[2] Smith, P.W., Bennett, G., Bradley, S., Drinka, P., Lautenbach, E., Marx, J., et al. (2008) SHEA/APIC Guideline: Infection Prevention and Control in the Long-Term Care Facility, July 2008. Infection Control and Hospital Epidemiology, 29, 785-814. https://doi.org/10.1086/592416

[3] Loeb, M., McGeer, A., McArthur, M., Peeling, R.W., Petric, M. and Simor, A.E. (2000) Surveillance for Outbreaks of Respiratory Tract Infections in Nursing Homes. Canadian Medical Association Journal, 162, 1133-1137.

[4] Sepkowitz, K.A. (1996) Occupationally Acquired Infections in Health Care Workers. Part I. Annals of Internal Medicine, 125, 826-834. https://doi.org/10.7326/0003-4819-125-10-199611150-00007

[5] Vareille, M., Kieninger, E. and Edwards, M.R. (2011) The Airway Epithelium: Soldier in the Fight against Respiratory Viruses. Clinical Microbiology Reviews, 24, 210-229. https://doi.org/10.1128/CMR.00014-10

[6] Clarsund, M., Fornbacke, M., Uller, L. and Ahlström Emanuelsson, C. (2014) Common Cold Prophylaxis Using ColdZyme Mouth Spray. XXXII Congress of the 
Nordic Association of Otolaryngology, Copenhagen, 22-24 May 2014.

[7] Nichol, K.L., Lind, A. and Margolis, K.L. (1995) The Effectiveness of Vaccination against Influenza in Healthy, Working Adults. New England Journal of Medicine, 333, 889-893. https://doi.org/10.1056/NEJM199510053331401

[8] Feeney, A., North, F., Head, J. and Canner, R. (1998) Socioeconomic and Sex Differentials in Reason for Sickness Absence from the Whitehall II Study. Occupational and Environmental Medicine, 55, 91-98. https://doi.org/10.1136/oem.55.2.91

[9] Hellgren, J., Cervin, A., Nordling, S., Bergman, A. and Cardell, L.O. (2010) Allergic Rhinitis and the Common Cold-High Cost to Society. Allergy, 65, 776-783. https://doi.org/10.1111/j.1398-9995.2009.02269.x

Submit or recommend next manuscript to SCIRP and we will provide best service for you:

Accepting pre-submission inquiries through Email, Facebook, LinkedIn, Twitter, etc. A wide selection of journals (inclusive of 9 subjects, more than 200 journals) Providing 24-hour high-quality service User-friendly online submission system Fair and swift peer-review system Efficient typesetting and proofreading procedure Display of the result of downloads and visits, as well as the number of cited articles Maximum dissemination of your research work

Submit your manuscript at: http://papersubmission.scirp.org/ Or contact ojrd@scirp.org 